\section{Responses of Garden Chrysanthemums to Daylength}

\author{
Kenneth E. Cockshull ${ }^{1}$ and Anton M. Kofranek \\ Department of Environmental Horticulture, University of California, \\ Davis, CA 95616
}

\author{
Additional index words. Chrysanthemum morifolium, Dendranthemum $\times$ grandiflorum, \\ flower initiation, flowering, response group
}

\begin{abstract}
Garden chrysanthemums [Dendranthemum xgrandiflorum (Ramat.) Kitamura] are characterized by early flowering in September and October when grown out-of-doors and by rapid flowering in short days (SD). However, as rooted cuttings of these cultivars frequently have flower buds present at the time of planting, their true response to daylength cannot readily be determined. Vegetative shoots were obtained by growing rooted cuttings in long days (LD), removing the terminal bud, and then pinching the emerging side shoots at a very early stage. On transfer to SD, the vegetative secondary side shoots quickly initiated flower buds that developed to anthesis more rapidly than those of 'Bright Golden Anne' (BGA), a lo-week response group cultivar. 'Bandit', 'Buckeye', 'Compatriot', 'Freedom', 'Jackpot', and 'Sunburst Cushion' appeared to be in the 7-week response group, with 'Baby Tears' in the 6-week and 'Powder River' in the 8-week response groups. All cultivars rapidly initiated flower buds in LD and, although they produced significantly more leaves than in SD, flower initiation began within $\approx 13 \mathrm{LD}$ from pinching. When pinched twice and grown using black cloth in summer, garden chrysanthemums can form attractive, uniformly flowering pot plants. Their rapid-flowering characteristic could also be of value in breeding programs for cut-flower chrysanthemums.
\end{abstract}

Garden chrysanthemums are a group of early flowering cultivars that can be planted out-of-doors in most areas of the United States from mid-May to July, for flowering in September and October. Early flowering chrysanthemums are generally quantitative shortday (SD) plants (Kawata and Toyoda, 1982; Langton, 1977, 1978), i.e., both flower initiation and flower development occur more rapidly in SD than in long days (LD), although a few are day-neutral or nearly so (Doorenbos, 19.55; Kawata and Toyoda, 1982; Langton, 1977, 1978). Many cultivars of garden chrysanthemums will flower in daylengths of 14.5 to $15 \mathrm{~h}$ (Chan, 1955; Seeley and Weise, 1965) or longer (Seeley and Weise, 1965); but most cultivars flower more rapidly in SD and will produce flowers in summer or for Mother's Day (Kofranek, 1950), with the aid of black cloth.

In addition to being early flowering, gar-

Received for publication 28 Dec. 1990. Accepted and G. Linson for their able technical assistance and Yoder Brothers, Inc. for the supply of rooted cuttings. The cost of publishing this paper was defrayed in part by the payment of page charges. Under postal regulations, this paper therefore must be hereby marked advertisement solely to indicate this fact.

'Present address: Horticulture Research International, Worthing Road, Littlehamptom, W. Sussex, BN17 6LP, England. for publication 6 Aug. 1991. We thank J. Kubota all, chrysanthemum cultivars eventually initiate a flower bud in LD (Cockshull, 1976; Cockshull and Kofranek, 1985; Kawata and Toyoda, 1982; Langton, 1977, 1978; Langton et al., 1982), but the regular appearance of flower buds at such an early stage indicates that garden chrysanthemums may have a limited potential for vegetative growth in LD. This potential can be assessed by decapitating (pinching) the cutting above a specific leaf on the main shoot, allowing side shoots to grow out in LD and then, when flower buds become visible, counting the number of leaves formed before the terminal flower of the side shoot. This number (the LD leaf number) is a measure of the duration of vegetative growth in LD. Pinching the cutting is advantageous because then the shoots are usually of similar physiological age at the start of the treatment (Cockshull, 1976; Cockshull and Kofranek, 1985; Langton and Cockshull, 1979). Two experiments were designed with the objectives of determining the LD leaf number of American garden cultivars and assessing their true speed of flower development in SD.

In the first experiment, 15 rooted stem cuttings of each of eight cultivars (Table 1) were planted on 28 June in 11-cm-diameter plastic pots (0.5 liter) containing equal parts of redwood shavings, peat, and sand (by volume). The cuttings were grown in a fan-andpad ventilated glasshouse with a minimum of $16 \mathrm{C}$, received natural LD ( $\leq 15 \mathrm{~h})$ augmented by a 4-h nightbreak (2300 to 0300 HR) from incandescent lamps at a photosynthetic photon flux density of 2.4 to 3.2 $\mu \mathrm{mol} \cdot \mathrm{m}^{-2} \cdot \mathrm{s}^{-1}$ and were supplied weekly with a complete mineral nutrient solution. By 11 July, flower buds were visible on plants of all but 'Jackpot' and 'Sunburst Cushion', but the degree of bud development varied within
Table 1. Number of leaves produced in long days (LD) by various shoot apical meristems and the stage of reproductive development of the same meristems of eight garden chrysanthemums before pinching, and the final number of leaves produced in LD and short days (SD) by the side shoot in the axil of the fourth leaf.

\begin{tabular}{|c|c|c|c|c|c|c|c|c|}
\hline \multirow[b]{4}{*}{ Cultivar } & \multicolumn{6}{|c|}{ Before pinching, 11 July } & & \\
\hline & \multicolumn{3}{|c|}{ Leaf no. } & \multicolumn{3}{|c|}{ Apical stage ${ }^{z}$} & \multirow{2}{*}{\multicolumn{2}{|c|}{ Final leaf no. }} \\
\hline & \multirow{2}{*}{$\begin{array}{l}\text { Main } \\
\text { shoot }\end{array}$} & \multirow{2}{*}{$\begin{array}{c}7 \text { th } \\
\text { axil }\end{array}$} & \multirow{2}{*}{$\begin{array}{l}\text { 4th } \\
\text { axil }\end{array}$} & \multirow{2}{*}{$\begin{array}{l}\text { Main } \\
\text { shoot }\end{array}$} & \multirow{2}{*}{$\begin{array}{l}\text { 7th } \\
\text { axil }\end{array}$} & \multirow{2}{*}{$\begin{array}{l}\text { 4th } \\
\text { axil }\end{array}$} & & \\
\hline & & & & & & & SD & LD \\
\hline Baby Tears & 7.8 & 5.4 & 8.0 & $\mathrm{FB}^{\mathrm{y}}$ & 7.4 & 5.6 & 7.8 & 10.6 \\
\hline Bandit & 12.2 & 8.4 & 11.2 & FB & 4.8 & 2.4 & 10.0 & 12.0 \\
\hline Buckeye & 10.8 & 7.4 & 10.2 & FB & 3.2 & 0.4 & 14.6 & $20.0^{*}$ \\
\hline Compatriot & 9.0 & 2.5 & 2.8 & FB & 7.0 & 6.4 & 6.4 & 2.2 \\
\hline Freedom & 11.8 & 11.0 & 11.8 & $\mathrm{FB}$ & 0.4 & 0.4 & 14.2 & $21.2^{*}$ \\
\hline Jackpot ${ }^{x}$ & 24.0 & 6.4 & 6.2 & 3.4 & 0 & 0 & 14.6 & $27.2^{*}$ \\
\hline Powder River & 12.0 & 10.0 & 7.0 & FB & 2.5 & 1.8 & 14.6 & 18.0 \\
\hline Sunburst Cushion ${ }^{\mathbf{x}}$ & 19.2 & 7.2 & 6.6 & FB & 0 & 0 & 17.4 & $26.0^{*}$ \\
\hline
\end{tabular}

${ }^{2}$ Apical stages were defined as $0=$ vegetative; $2=$ some bracts present; $4=$ many bracts present but no florets; 6 = six rows of florets present. After Cathey and Borthwick (1957).

${ }^{y} \mathrm{FB}=$ flower bud present.

${ }^{x}$ Pinched above seventh leaf axil.

*LD and SD means differ significantly at $\mathrm{P}=0.05$ 


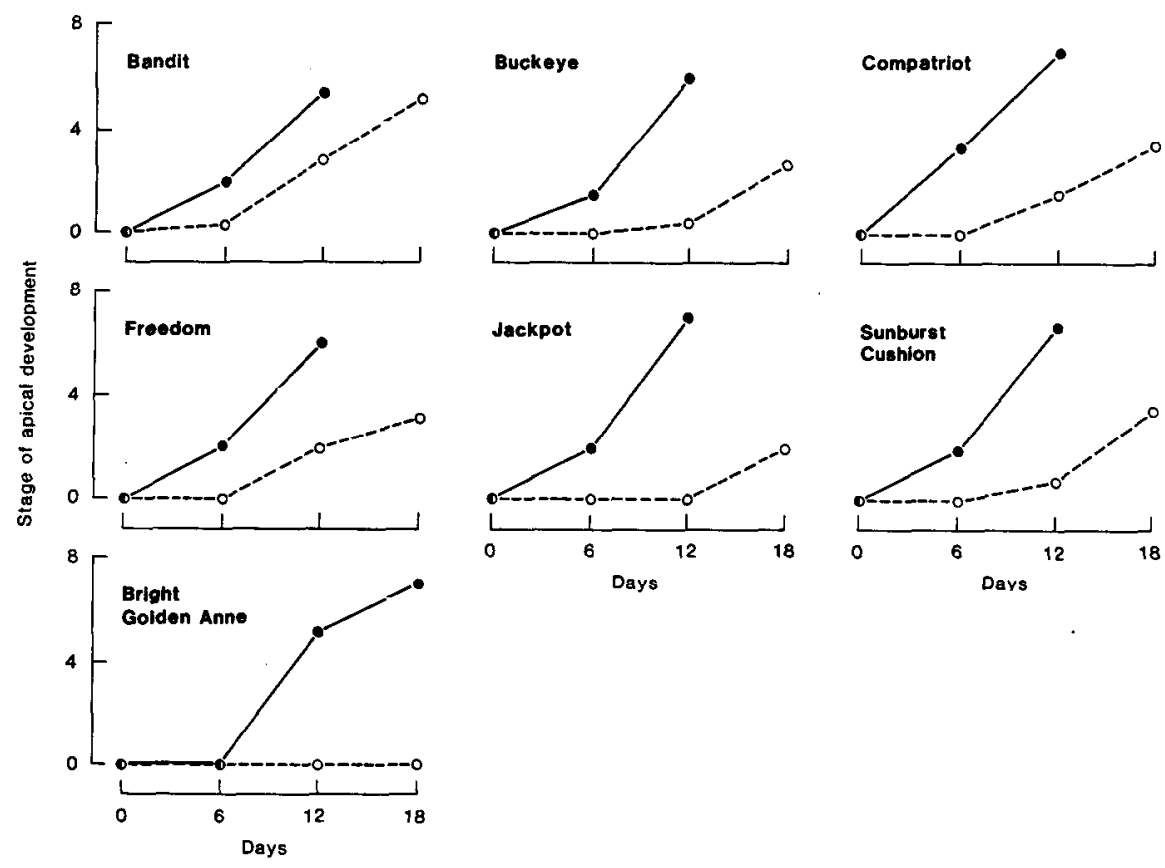

Fig. 1. The effects of daylength on flower initiation and development in six garden chrysanthemums and 'Bright Golden Anne'. Short days $(\mathbf{0})$; long days $(O)$. Stages of flower initiation after Cathey and Borthwick (1957), where $0=$ vegetative; $2=$ some bracts present; $4=$ many bracts present but no florets; $6=$ six rows of florets present; 89 = capitulum almost covered with florets.

Table 2. Number of leaves produced in long days (LD) by the shoot meristem in the axil of the second leaf on side shoots of six garden chrysanthemums and 'Bright Golden Anne', and the stage of reproductive development of the same meristem, prior to the second pinch (14 July). The average rates of leaf initiation and emergence in $\mathrm{LD}$, the final leaf numbers in $\mathrm{LD}$ and short days $(\mathrm{SD})$, and the estimated duration of vegetative growth in LD of the shoot in the axil of the second leaf, after the second pinch.

\begin{tabular}{|c|c|c|c|c|c|c|}
\hline \multirow[b]{3}{*}{ Cultivar } & \multirow{3}{*}{$\begin{array}{c}\text { Before second } \\
\text { pinch }^{\mathbf{z}} \\
\text { (no. leaves) }\end{array}$} & \multicolumn{5}{|c|}{ After second pinch } \\
\hline & & \multicolumn{2}{|c|}{ Rate (leaves/day) } & \multicolumn{2}{|c|}{$\begin{array}{c}\text { Final no. } \\
\text { leaves }\end{array}$} & \multirow{2}{*}{$\begin{array}{l}\text { Duration } \\
\text { vegetative } \\
\text { growth in } \\
\text { LD (days) }\end{array}$} \\
\hline & & Initiation & Emergence & SD & LD & \\
\hline Bandit & 6.0 & 1.80 & 0.67 & 12.2 & $15.9^{*}$ & 6.1 \\
\hline Buckeye & 5.4 & 1.20 & 0.57 & 9.5 & $18.4^{*}$ & 11.7 \\
\hline Compatriot & 5.4 & 1.83 & 0.83 & 12.8 & $20.6^{*}$ & 8.9 \\
\hline Freedom & 6.6 & 1.47 & 0.83 & 12.2 & $17.3^{*}$ & 8.0 \\
\hline Jackpot & 6.2 & 1.57 & 1.07 & 11.4 & $24.9^{*}$ & 12.6 \\
\hline Sunburst Cushiony & 5.6 & 1.70 & 1.30 & 12.1 & $26.3^{*}$ & 12.8 \\
\hline Bright Golden Anne & 4.0 & 1.00 & 0.47 & 8.5 & $20.4^{*}$ & 17.4 \\
\hline
\end{tabular}

${ }^{2}$ The apical stage was 0 for all cultivars, where $0=$ vegetative; $2=$ some bracts present; $4=$ many bracts present but no florets; $6=$ six rows of florets present. After Cathey and Borthwick (1957). 'Shoot in axil of fourth leaf.

*LD and SD means differ significantly at $P=0.05$.

cultivars. To ensure all stages of development were represented in each treatment, the 15 plants of each cultivar were ranked in order of increasing bud development and divided into five successive groups. Each group contained three plants, one of which was transferred to SD of $8.5 \mathrm{~h}$ daylight ( 0815 to $1645 \mathrm{HR}$ daily), one was maintained in the original LD treatment, while the remaining one was sampled.

The shoot tip of each sampled plant was examined, and dissected if necessary, to assess the stage of development of the apical meristem (Cathey and Borthwick, 1957). The number of leaves and primordia that had been initiated on the main shoot was recorded and the meristems in the axils of the fourth and seventh leaves from the base of the main shoot were also examined to assess their development. Our standard practice is to allow the side shoot in the axil of the seventh leaf to develop after pinching (Cockshull, 1976; Cockshull and Kofranek, 1985; Langton and Cockshull, 1979; Langton et al., 1982), but only 'Jackpot' and 'Sunburst Cushion' had vegetative meristems in this leaf axil (Table 1). These two cultivars were given a soft pinch above the seventh leaf while the others were given a hard pinch, into mature stem tissue above the fourth leaf, as reproductive development was less in this leaf axil (Table 1).

All plants were pinched on 11 July. Later, when flower buds were visible, the leaves formed before the terminal bud on the uppermost side shoot were counted. Bracts and bract-like leaves with entire margins were excluded from the count as their formation marks the transition to flower initiation (Horridge and Cockshull, 1979). The date of anthesis (flower stage 8; Cockshull and Hughes, 1972) of the terminal flower of the uppermost shoot was also recorded in SD.

In the second experiment, a more rigorous attempt was made to obtain vegetative material at the onset of treatment. One hundred rooted stem cuttings of each of six garden cultivars (Table 2) were planted in $16-\mathrm{cm}-$ diameter pots ( 0.8 liter) on 28 June, together with 100 cuttings of 'Bright Golden Anne' (BGA), and cultivated as in the first experiment but with a 6-h night break (2100 to $0300 \mathrm{HR}$ ) from incandescent lamps (2.4 to $\left.3.2 \mu \mathrm{mol} \cdot \mathrm{m}^{-2} \cdot \mathrm{s}^{-1}\right)$. Each plant was given a soft pinch above the eighth leaf on 5 July, and all side-shoots except the one in the axil of the sixth leaf were removed on 13 July. On this date, 65 uniform plants, free of obvious flower buds, were selected of each cultivar. A sample of five plants of each cultivar was taken on 14 July. The apical meristem of the shoot in the axil of the sixth leaf was dissected to determine its stage of development and the number of initiated leaves and leaf primordia. All cultivars except BGA had initiated a terminal flower on this shoot, even though the plants were still in LD and the average shoot length was generally $<3 \mathrm{~cm}$. Further examination showed that the meristem in the axil of the second leaf from the base of the side shoot was still vegetative (Table 2), because primary and secondary axillary meristems do not differ in their reproductive behavior in LD (Votruba, 1981), this axillary bud was chosen to provide the treated shoot. Side shoots were given a soft pinch above their second leaf (14 July) by use of a scalpel to avoid damage to the axillary bud. 'Sunburst Cushion' was pinched above the fourth leaf, as there was often no meristem present in the axil of the second. Thirty plants were then transferred to SD $(8$ $\mathrm{h}$ daylight from 0815 to $1615 \mathrm{HR}$ ) and 30 were retained in $\mathrm{LD}$.

The development of the secondary side shoot was followed by taking samples of five plants per cultivar at 6,12 , and 18 days from pinching. At each sampling, the number of emerged leaves longer than $15 \mathrm{~mm}$, the shoot length, the stage of development of the apical meristem, and the total number of initiated leaves and leaf primordia were recorded. Rates of leaf initiation were calculated from the number of leaves present in the axillary bud at pinching and after $6 \mathrm{LD}$, and rates of leaf emergence from the numbers of leaves emerged after 12 and 18 LD from pinching. The number of leaves on 10 shoots was counted when all had produced visible flower buds in SD and LD, and the date of anthesis of the terminal flower bud of 15 shoots was recorded in SD.

In the first experiment, reproductive development of even the apical meristem in the axil of the fourth leaf was well advanced in 'Baby Tears', 'Bandit'., and 'Compatriot' at the time of pinching (Table 1); thus, the LD leaf number and time to anthesis in SD were 
Table 3. Days to anthesis of terminal flower bud in short days, corrected by multiplying by 1.165 , which converts days to anthesis of 'Bright Golden Anne' to 70 days, and estimated response groups of eight garden chrysanthemums.

\begin{tabular}{|c|c|c|c|c|c|}
\hline \multirow[b]{2}{*}{ Cultivar } & \multicolumn{2}{|c|}{ Observed days to anthesis ${ }^{x, y}$} & \multicolumn{2}{|c|}{ Corrected days to anthesis } & \multirow{2}{*}{$\begin{array}{c}\text { Estimated } \\
\text { response } \\
\text { group } \\
\text { (weeks) }\end{array}$} \\
\hline & $\begin{array}{l}\text { First } \\
\text { expt. }\end{array}$ & $\begin{array}{l}\text { Second } \\
\text { expt. }\end{array}$ & $\begin{array}{l}\text { First } \\
\text { expt. }\end{array}$ & $\begin{array}{l}\text { Second } \\
\text { expt. }\end{array}$ & \\
\hline Baby Tears & $37.8 \mathrm{a}$ &.- & 44.1 & --- & 6 \\
\hline Bandit & $40.2 \mathrm{~b}$ & $45.0 \mathrm{~d}$ & 46.8 & 52.1 & 7 \\
\hline Buckeye & $44.8 d$ & $44.9 \mathrm{~d}$ & 52.2 & 52.3 & 7 \\
\hline Compatriot & $39.4 \mathrm{~b}$ & $43.9 \mathrm{c}$ & 45.9 & 51.1 & 7 \\
\hline Freedom & $42.2 \mathrm{c}$ & $43.0 \mathrm{~b}$ & 49.2 & 50.1 & 7 \\
\hline Jackpot & $45.4 \mathrm{~d}$ & $44.2 \mathrm{~cd}$ & 52.9 & 51.5 & 7 \\
\hline Powder River & $47.6 \mathrm{e}$ & -.. & 55.5 & $\ldots$ & 8 \\
\hline Sunburst Cushion & $44.6 \mathrm{~d}$ & $41.9 \mathrm{a}$ & 52.0 & 48.8 & 7 \\
\hline Bright Golden Anne & -- & $60.1 \mathrm{e}$ & $\ldots$ & 70.0 & 10 \\
\hline
\end{tabular}

${ }^{2}$ Mean separation by Duncan's multiple range test, $\mathrm{P}=0.05$.

${ }^{y}$ Anthesis = stage 8 (outer ray florets fully expanded) (Cockshull and Hughes, 1982).

probably underestimated in these cultivars. In the second experiment, the axillary meristems were vegetative at the time of pinching; the LD leaf numbers of 'Bandit' and 'Compatriot' were then higher (Table 2) and both cultivars required about five more SD to reach anthesis (Table 3 ).

All garden cultivars tested had LD leaf numbers $<30$ and produced leaf primordia more rapidly than BGA (Table 2). Consequently, all began to initiate flower buds very early in LD. Although the side shoots of BGA were still apparently vegetative after 18 LD (Fig. 1), the side shoots of all the garden cultivars had begun to form flower buds by this time, and those of 'Bandit', 'Compatriot', and 'Freedom' had already initiated some bracts (stage 2) within 12 LD from pinching. If the formation of the first bract marks the transition to flower initiation (Horridge and Cockshull, 1979), the time when bract initiation occurred can be estimated by subtracting the number of leaves and primordia initially present in the axillary bud from the final LD leaf number plus one (i.e., the first bract) and dividing this number by the rate of leaf initiation. Axillary shoot meristems of 'Bandit', 'Compatriot', and 'Freedom' initiated their first bract $\approx 1$ week after pinching in LD, while those of 'Buckeye', 'Jackpot' and 'Sunburst Cushion' did so after $\approx 13$ days (Table 2 ). Shoots of all these cultivars, therefore, will be prone to begin flower initiation while still on the stock plant in LD.

All garden cultivars tested in the second experiment produced significantly fewer leaves in SD than LD, indicating flower initiation was promoted by SD when starting with vegetative material. Furthermore, both flower bud initiation and development proceeded rapidly in SD (Fig. 1; Table 3). All garden cultivars reached anthesis in $<43 \mathrm{SD}$, while BGA reached anthesis in $60 \mathrm{SD}$ (Table 3 ). BGA is normally classed as belonging to the lo-week (70-day) response group for fall flowering and so some adjustment must be made to allow for the environmental conditions (i.e., summer in central California) under which these experiments were conducted. Most simply, multiply the data by 1.165 (i.e., $70 / 60.1$, Table 3) to correct the BGA response to 70 days. When adjusted in the same way, the corrected values for the other cul- tivars in the second experiment were between 49 and 52 days (Table 3), indicating that they should be classed in the 7-week response group. 'Bandit' and 'Compatriot' have previously been classed by Yoder Brothers, Inc., in the 6-week response group, probably because rooted cuttings are usually budded. If the data of the first experiment are corrected in a similar way, lower values are obtained for 'Bandit' and 'Compatriot' (Table 3), which had begun to initiate flowers before SD treatment. 'Powder River' appeared to be less responsive and probably merits classification in the 8-week response group. In these experiments, in which the natural LD was augmented by a 6-h nightbreak, the further development of flower buds of most cultivars was arrested in LD, though some flower buds of 'Baby Tears' and 'Compatriot' did reach anthesis.

The rapid-flowering characteristic shown by garden chrysanthemums in SD could be of value if introduced into cultivars bred for year-round production. Although rapid flowering in SD is associated with a tendency to also initiate flowers rapidly in $\mathrm{LD}$, the association was not inevitable in unselected progenies of late-flowering types (Langton and Dixon, 1984). Speed of flower development in SD, however, is likely to be associated with high rates of leaf emergence and with short internodes (Langton and Dixon, 1984). For cut flowers, therefore, in one strategy garden cultivars could be crossed with cultivars that initiate flowers quickly in SD but have high LD leaf numbers (Cockshull and Kofranek, 1985). This procedure likely will produce some progeny that combine rapid flowering in SD with freedom from the tendency to form buds on stock plants and on cuttings in LD. Alternatively, (2chloroethyl)phosphonic acid (ethephon) could be applied to stock plants to delay flower initiation in LD (Cockshull and Horridge, 1978; Cockshull et al., 1979), but the effect must be dissipated before the onset of SD.

Finally, the presence of a flower loud at the terminal apical meristem of a shoot in LD can influence the development of axillary meristems, especially those immediately adjacent (Langton, 1977, 1978). This influence was evident in the first experiment, for the lower the leaf count of the main shoot in $\mathrm{LD}$, the closer the seventh leaf was to the bud and the more advanced the development of its own axillary meristem (Table 1), while development of axillary meristems of lower leaves, e.g., the fourth, was less advanced.

Garden chrysanthemums can make attractive, uniform pot plants if given two pinches (to obtain vegetative side shoots) and then shaded with black cloth, but their usefulness would be increased if the ability to initiate and develop flowers rapidly in SD were combined with a high LD leaf number.

\section{Literature Cited}

Cathey, H.M. and H.A. Borthwick. 1957. Photoreversibility of flower initiation in chrysanthemum. Bot. Gaz. 119:71-76.

Chan, A.P. 1955. Some factors affecting flower bud development of chrysanthemums. Rpt. 14th Intl. Hort. Congr. 2:1023-1039.

Cockshull, K.E. 1976. Flower and leaf initiation by Chrysanthemum morifolium Ramat. in long days. J. Hort. Sci. 51:441-450.

Cockshull, K.E. and J.S. Horridge. 1978. 2chlorethylphosphonic acid and flower initiation by Chrysanthemum morifolium Ramat. in short days and in long days. J. Hort. Sci. 53:85-90.

Cockshull, K.E. and A.P. Hughes. 1972. Flower formation in Chrysanthemum morifolium: the influence of light level. J. Hort. Sci. 47:113127.

Cockshull, K.E. and A.M. Kofranek. 1985. Longday flower initiation by chrysanthemum. HortScience 20:296-298.

Cockshull, K.E., J.S. Horridge, and F.A. Langton. 1979. Ethephon and the delay of early budding in chrysanthemums. J. Hort. Sci. 54:337338.

Doorenbos, J. 1955. Daglente en bloei bij Chrysanthemum morifolium. Meded. Dir. Tuinbouw 18:375-390

Horridge, J.S. and K.E. Cockshull. 1979. Size of the Chrysanthemum shoot apex in relation to inflorescence initiation and development. Ann. Bot. 44:547-556.

Kawata, J. and T. Toyoda. 1982. The responses to photoperiod and temperature of Japanese July to September flowering chrysanthemums. Acta Hort. 125:93-99.

Kofranek, A.M. 1950. Hardy chrysanthemum pot plants for Mothers Day. Florists Rev. 105(2724):27.

Langton, F.A. 1977. The responses of early-flowering chrysanthemums to daylength. Scientia Hort. 7:277-289.

Langton, F.A. 1978. Photoperiod responses of some Japanese chrysanthemums. J. Jpn. Soc. Hort. Sci. 47:237-242.

Langton, F.A. and K.E. Cockshull. 1979. Screening chrysanthemums for leaf number in long days. Rpt. Glasshouse Crops Res. Inst. 1978:177-186.

Langton, F.A. and T.J. Dixon. 1984. Long-day leaf number in the chrysanthemum (C. morifolium Ramat.): Inheritance and correlative associations with three other characters. Z. Pflanzenzüchtg. 92:249-258.

Langton, F.A., H.M. Royce, and K.E. Cockshull. 1982. Leaf numbers of chrysanthemums grown in long days. Tests of agrochemicals and cultivars. Ann. Applied Biol. 100, Suppl. 3:110111.

Seeley, J.G. and A.H. Weise. 1965. Photoperiohic response of garden and greenhouse chrysanthemums. Proc. Amer. Soc. Hort. Sci. $87: 464-471$

Votruba, R. 1981. Premature budding in Chvsanthemum morifoium in relation to the age of stock plants. Acta Hort. 125:111-117. 